\title{
ANALISIS KURANGNYA MINAT MAHASISWA MEMILIH PROGRAM STUDI PENDIDIKAN BAHASA ARAB DI STAIN DATOKARAMA PALU
}

\author{
Kasmiati \\ STAIN Datokarama Palu, Jl. Diponegoro 23 Palu \\ e-mail: kasmiatiridho@yahoo.com
}

\section{Abstract}

This research deals with the lack of interest of the students in Arabic Language Teaching Program at STAIN Datokarama Palu. This research is intended to describe the factors that make the students have low in interest in Arabic Teachiung Program. The results shows that decreasing interest is much more associated with (1) the lack of opportunity to find jobs, especially to be civil servants; (2) the influence their counterparts to make a similar choice; and (3) the deminishing promotion of this program to the prospective students. The efforts have to be made in order to get much more students are incessant promotion of this program to public, intensive Arabic preparation for students and curriculum improvement.

يتعلق هذا البحث بدراسة تدنى رغبة الطلاب فى شعبة تربية اللغة العربية فى

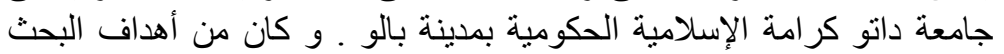



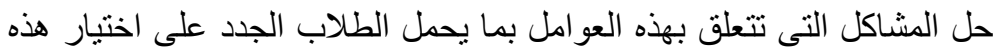

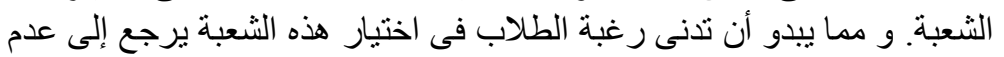

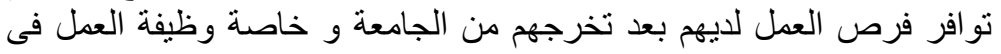

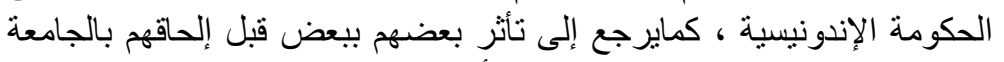

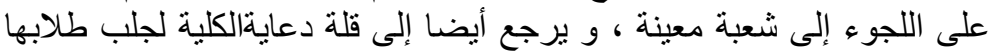

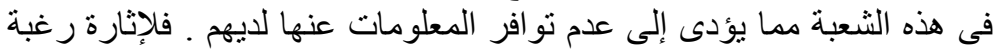

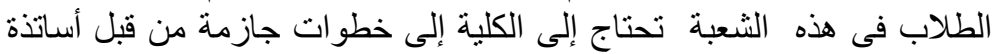

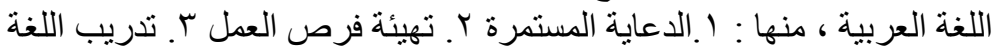

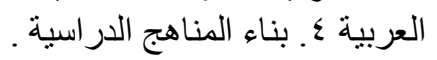

Kata Kunci: minat, pendidikan bahasa Arab, sosialiasi, lapangan kerja 


\section{PENDAHULUAN}

Bahasa Arab - sebagai salah satu bahasa yang menjadi "bahasa ibu" lebih dari 200 juta umat manusia yang tersebar pada kurang lebih 20 negara (Arsyad, 1994:1) — memiliki banyak keistimewaan dan ciri khas yang membedakannya dengan bahasa lainnya, khususnya kedudukan bahasa Arab sebagai lingua franca bagi umat Islam.

Alquran diwahyukan kepada Rasulullah saw. dengan menggunakan bahasa Arab, sebagaimana firman Allah dalam surat Al-Zukhruf (43):3.

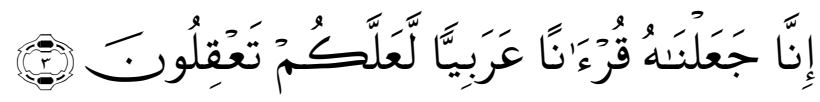

Terjemahnya:

"Sesungguhnya kami menjadikan Alqur'an dalam bahasa Arab supaya kamu memahaminya".

Rasulullah saw. yang berasal dari suku Quraisy (salah satu kabilah bangsa Arab) juga berbicara dalam bahasa Arab. Dengan demikian, hadis sebagai sumber pokok kedua ajaran Islam juga menggunakan bahasa Arab dalam mengkomunikasikan pesanpesannya disebabkan konteks sosio-historis agama Islam yang pertama kali muncul dan berkembang di jazirah Arab.

Kebanyakan diskursus tentang keislaman yang ditulis oleh para ulama dan cendekiawan muslim menggunakan bahasa Arab yang diakui sebagai lingua franca dalam diskursus akademis dunia Islam. Para ulama sejak abad pertengahan menulis banyak kitab dengan menggunakan bahasa Arab, baik kitab tauhid, tafsir, hadis, fikih, tasawuf dan sebagainya. Bahasa Arab juga menjadi bahasa akademis bagi umat Islam yang harus dipelajari oleh setiap muslim, terutama yang ingin lebih mendalami ajaran Islam (Al-Ghazâlî, 1971: 351-352).

Karena pentingnya pembelajaran bahasa Arab bagi pendalaman ilmu-ilmu keislaman, Sekolah Tinggi Agama Islam Negeri (STAIN Datokarama Palu, sebagai Perguruan Tinggi Islam Negeri, membuka program studi Pendidikan Bahasa Arab (PBA) dalam lingkup Jurusan Tarbiyah. Namun demikian, kenyataan menujukkan bahwa dari tahun ke tahun terjadi penurunan jumlah mahasiswa yang memilih program 
studi PBA. Hal ini menunjukkan kecenderungan kurangnya minat mahasiswa untuk menyelesaikan studinya di program studi tersebut. Sehubungan dengan hal tersebut, masalah yang dibahas dalam tulisan ini ialah:(1) faktor-faktor penyebab kurangnya minat mahasiswa memilih program studi PBA di STAIN Datokarama Palu; dan (2) langkah-langkah yang perlu dilakukan untuk menarik minat mahasiswa memilih program studi tersebut.

\section{METODE PENELITIAN}

Jenis penelitian ini adalah survey yang berorientasi pada fenomena atau gejala yang bersifat alami (Ali, 1993:156). Populasi penelitian ini adalah seluruh mahasiswa, dosen, ketua program studi serta ketua jurusan di lingkungan STAIN Datokarama Palu. Tidak semua populasi diteliti, sehingga dipergunakan teknik proposional random sampling sebanyak $25 \%$ pada tiga angkatan mahasiswa (angkatan 2003 s.d. 2005), yaitu: (1) 65 orang mahasiswa angkatan 2003 (25\% dari 262 orang); (2) 80 orang mahasiswa angkatan 2004 (25\% dari 320 orang); dan (3) 77 orang mahasiswa angkatan 2005 (25\% dari 308 orang), sehingga total sampel berjumlah 222 orang.

Metode penelitian ini adalah studi kasus, yaitu penelitian yang berorientasi pada kenyataan atau kejadian yang terjadi di lapangan, khususnya kurangnya minat mahasiswa baru memilih Program Studi PBA di STAIN Datokarama Palu. Metode pendekatan yang digunakan adalah pedagogis dan psikologis.

Pengumpulan data dilakukan dengan dua metode, yaitu: (1) metode kepustakaan (library research) dengan tiga teknik, yakni kutipan langsung, kutipan tidak langsung dan ikhtisar; serta metode penelitian lapangan (field research) dengan tiga teknik, yakni observasi, wawancara dan angket. Data yang terkumpul, kemudian dianalisis dengan menggunakan teknik siklus analisis data secara deskro, yaitu reduksi data, penyajian data, dan verfikasi data. Keseluruhan langkah-langkah itu dijadikan tujuan dalam mengelola dan menganalisis data yang diperoleh dari hasil penelitian. Himpunan data diolah dengan menggunakan analisis persentase, kemudian ditafsirkan secara kualitatif. 


\section{HASIL DAN ANALISIS}

\section{Profil STAIN Datokarama Palu}

Sejak terbitnya Surat Keputusan Presiden R.I. Tahun 1997 Tentang Pendirian STAIN, Keputusan Dirjen Bimbaga Islam Nomor : E/136/1997 Tentang Alih Status dari Fakultas Daerah Menjadi STAIN, dan Keputusan Menteri Agama R.I. Nomor 403 Tahun 1993 tentang Statuta STAIN Datokarama Palu maka dua Fakultas daerah, yaitu Fakultas Tarbiyah dan Fakultas Ushuluddin yang selama ini berada di bawah naungan dan binaan IAIN Alauddin Ujung Pandang (sekarang Makassar) resmi menjadi Sekolah Tinggi Agama Islam Negeri (STAIN) dengan nama STAIN Datokarama Palu.

STAIN Datokarama Palu telah melakukan berbagai bidang pengembangan. Pada tanggal 17 September 1997 telah dilakukan penandatanganan berita acara Ketua STAIN Datokarama Palu dengan Ketua Yayasan Datokarama atas integrasi STIS Datokarama Palu menjadi salah satu Jurusan Syari'ah pada STAIN Datokarama Palu. Pada tahun 1998 melalui SK Ketua STAIN Datokarama Palu Nomor 66.a Tahun 1998 telah dibuka pula Jurusan Dakwah dengan program studi Komunikasi dan Penyiaran Islam (KPI). Sampai pada tahun 1998, STAIN Datokarama Palu memiliki 11 program studi, yaitu : Jurusan Tarbiyah dengan program studi Pendidikan Agama Islam (PAI), Pendidikan Bahasa Arab (PBA), Kependidikan Islam (KI), dan Program Diploma 2 (D 2) yaitu Pendidikan Guru Kelas Madrasah Ibtidaiyah (PGKMI) dan Guru Pendidikan Agama Islam (GPAI). Jurusan Ushuluddin dengan program studi: Aqidah Filsafat (AF), Perbandingan Agama (PA) dan Tafsir Hadis (TH). Jurusan Syari'ah memiliki program studi Perbandingan Madzhab dan Hukum (PMH) dan Muamalah (MUA). Sedangkan Jurusan Dakwah dengan program studi Komunikasi dan Penyiaran Islam (KPI). Pada tahun akdemik 2000/2001, STAIN Datokarama Palu bekerja sama dengan IAIN Alauddin Makassar membuka Program Pascasarjana dengan konsentrasi Pendidikan Islam dan Hukum Islam. Selain itu, STAIN Datokarama Palu memiliki beberapa lembaga non struktural, yaitu Perpustakaan, Unit Komputer, Unit Pengembangan Bahasa (UPB, Pusat Penelitian dan Pengabdian pada Masyarakat (P3M), UPMA, dan Pusat Studi Gender (PSQ). 
STAIN Datokarama Palu juga melakukan peningkatan kualitas dosen. Ada 37 dosen yang sedang mengikuti pendidikan Strata Tiga (S3), 2 orang telah menyelesaikan studinya. Untuk jenjang strata dua (S2) sebanyak 36 orang, sedangkan yang lain masih berjenjang strata satu. Tenaga administrasi STAIN Datokarama Palu berjumlah 34 orang berpendidikan SMA dan Strata Satu. Dari segi mahasiswa, jumlah keseluruhannya pada tahun 2003 adalah 1.376 orang, terdiri atas 619 laki-laki dan 757 perempuan.

\section{Kerangka Teori}

Dalam Kamus Besar Bahasa Indonesia dikemukakan pengertian minat adalah "kecenderungan yang tinggi terhadap sesuatu, gairah atau keinginan" (Depdikbud, 1990:70). Taher (1981:100) mengemukakan pengertian minat sebagai "perhatian yang mengandung unsur-unsur perasaan." Dari dua pengertian ini dapat dipahami bahwa minat adalah kecenderungan yang tinggi, mengandung unsur-unsur perasaan terhadap sesuatu, gairah, dan keinginan. Dengan demikian, minat merupakan sesuatu yang lahir dalam diri seseorang untuk tertarik pada sesuatu yang akan berpengaruh dalam pengambilan keputusan.

Pada prinsipnya, pengambilan keputusan diawali dengan persoalan, memperjelas sasarannya, dan mengidentifikasi semua pilihan yang mungkin untuk memecahkan persoalan tersebut secara objektif (Demand, 1993:3). Pokok-pokok pikiran yang tersirat dalam pengambilan keputusan melalui beberapa tahapan yang dapat digambarkan sebagai berikut:

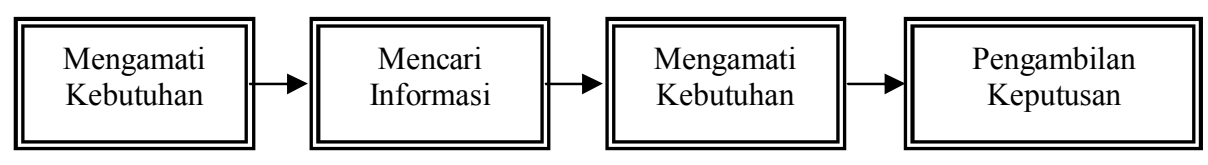

Dengan mengacu pada gambaran tahapan pengambilan keputusan tersebut maka terlihat jelas bahwa mahasiswa telah melalui beberapa tahapan sebelum mengambil keputusan melanjutkan pendidikan tingginya pada suatu program studi, termasuk mempertimbangkan terlebih dahulu apakah suatu program studi yang dipilih akan memberikan manfaat atau kepuasan pada dirinya, ataukah malah mempersulit dirinya di masa kini dan masa yang akan datang. 


\section{Pendidikan Bahasa Arab}

Istilah pendidikan berasal dari kata "didik" yang bermakna memelihara dan memberi latihan mengenai akhlak dan kecerdasan pikiran (Purwadarminta, 1985:250). Marimba (t.th.:19) memberikan pengertian pendidikan sebagai "bimbingan atau pimpinan secara sadar oleh si pendidik terhadap perkembangan jasmani dan rohani si terdidik menuju terbentuknya kepribadian yang utama." Sedangkan bahasa Arab adalah "kalimat yang digunakan bangsa Arab dalam mengutarakan maksud dan tujuan mereka" (Al-Ghulâyânî, 1992:13). Dengan demikian, yang dimaksud dengan pendidikan bahasa Arab adalah bimbingan atau pimpinan secara sadar oleh si pendidik terhadap anak didik tentang bahasa Arab.

\section{Faktor-faktor Penyebab Kurangnya Minat Mahasiswa dalam Memilih Program Studi Pendidikan Bahasa Arab}

Sebenarnya mahasiswa cenderung berminat belajar bahasa Arab. Data menunjukkan bahwa 136 responden (61\%) menyatakan berminat belajar bahasa Arab, 17 responden (8\%) menyatakan kurang berminat, dan hanya 69 (31\%) menyatakan biasa saja. Minat terhadap bahasa Arab sebenarnya dapat menjadi faktor pendorong bagi mahasiswa untuk belajar bahasa Arab. Namun demikian, kenyataan menunjukkan bahwa mahasiswa kurang berminat untuk mendalami studi bahasa Arab pada program studi PBA. Pada tahun 2003 terdapat 262 mahasiswa baru yang diterima di STAIN Datokarama Palu, namun hanya 10 orang $(3,81 \%)$ yang memilih program studi PBA. Pada tahun 2004, ada 320 mahasiswa baru, tetapi hanya 12 orang $(3,75 \%)$ yang memilih program studi PBA. Pada tahun 2005, terdapat 308 mahasiswa baru, namun hanya 12 orang (3,89\%) yang memilih program studi PBA.

Ada beberapa faktor yang melatarbelakangi kurangnya minat mahasiswa memilih program studi PBA, yaitu: pertama, mahasiswa kurang memiliki pengetahuan dasar bahasa Arab. Kebanyakan responden, yaitu 143 orang (65\%) menjawab bahwa mereka tidak memilih program studi PBA karena kurang memiliki pengetahuan dasar bahasa Arab. Alasan lain yang dikemukakan oleh responden adalah kurang berminat pada mata pelajaran bahasa Arab, yaitu 38 responden (17\%) dan berminat pada program studi lain 41 responden 
(18\%). Hal ini menunjukkan bahwa penguasaan pengetahuan -dasar bahasa Arab yang menjadi salah satu faktor signifikan mengapa mahasiswa tidak memilih program studi PBA di STAIN Datokarama Palu.

Kedua, kekhawatiran dalam memperoleh pekerjaan, khususnya kesempatan untuk menjadi Pegawai Negeri Sipil (PNS). Banyak orang tua yang menginginkan anaknya setelah menyelesaikan kuliah di perguruan tinggi akan menjadi PNS. Hasil angket menunjukkan bahwa kebanyakan responden, yaitu 121 responden $(55,5 \%)$ menyatakan bahwa orang tua mereka menginginkan anaknya menjadi PNS setelah menyelesaikan kuliah di STAIN Datokarama Palu. Hanya 96 responden $(44,3 \%)$ menjawab untuk menuntut ilmu dan 5 responden $(0,2 \%)$ menjawab untuk meraih gelar kesarjanaan.

Fakta menunjukkan di tengah-tengah masyarakat Sulawesi Tengah, sarjana lulusan program studi PBA agak susah untuk menjadi PNS dikarenakan jumlah formasi penerimaan CPNS untuk lulusan program studi PBA sangat sedikit, sementara lulusan program studi PBA sangat banyak.

Abd. Rahim, dosen bahasa Arab, menyatakan sebagai berikut:

Pernah terjadi 3 tahun berturut-turut formasi penerimaan PNS untuk sarjana bahasa Arab tidak ada sama sekali. Hal ini sangat berpengaruh pada mahasiswa sehingga kurang berminat memilih program studi PBA. 180 responden (81\%) menyatakan bahwa mereka tidak memilih PBA karena adanya fakta kurangnya peluang PBA menjadi PNS, hanya 27 responden (12\%) menjawab tidak, dan 15 responden (7\%) menjawab belum tentu. (Wawancara, 17 Juni 2006).

Hal ini diperkuat oleh hasil wawancara penulis dengan dosen bahasa Arab yang lain, M. Nur Aswami, yang mengatakan bahwa:

Ada kemungkinan kurangya peluang menjadi PNS inilah yang menyebabkan orang tua tidak mengizinkan anaknya memilih program studi PBA, meskipun anaknya berminat untuk melanjutkan studinya di program studi ini (Wawancara, 17 Juni 2006).

Ketiga, pengaruh dari orang lain. Dalam memilih program studi di STAIN Datokarama Palu, 103 responden (46\%) menyatakan mereka memilih sendiri. Walaupun data ini menunjukkan bahwa banyak responden yang memilih sendiri program studinya, data ini 
menunjukkan bahwa pengaruh orang lain sangat besar pula dalam menentukan mahasiswa memilih program studi, yaitu 119 responden (54\%), yaitu 70 responden (32\%) menyatakan dipilihkan orang tua dan 49 responden (22\%) menyatakan ikut-ikutan teman. Pengaruh dari orang tua kemungkinan besar sangat berkaitan dengan harapan orang tua kelak anaknya bisa menjadi PNS setelah lulus dari STAIN Datokarama Palu, sedangkan pengaruh dari teman-teman terkadang disebabkan oleh kesamaan asal sekolah, maupun informasi kurangnya lapangan pekerjaan bagi lulusan program studi PBA.

Keempat, kurangnya sosialisasi program studi PBA pada calon mahasiswa baru. Calon mahasiswa yang berasal dari berbagai daerah terkadang memperoleh informasi tentang program studi PBA hanya secara sepintas. Padahal informasi yang detail tentang keberadaan program studi PBA perlu diberikan untuk memotivasi calon mahasiswa memilih program studi PBA. Dari data yang terkumpul ditemukan bahwa 61 responden $(28 \%)$ menyakatan memperoleh informasi tentang program studi PBA dari teman, 49 responden $(22 \%)$ menyatakan melalui brosur yang dibagikan, 43 responden (19\%) melalui dosen STAIN Datokarama Palu, sedangkan 63 responden (31\%) menyatakan memperoleh informasi melalui sosialisasi di televisi (siaran TVRI Palu, khususnya siaran Berita Kareba Kakomiu). Sosialisasi melalui dosen, brosur, serta media televisi memang berhasil menginformasikan keberadaan STAIN Datokarama Palu, tetapi belum dapat dikatakan berhasil dalam mensosialisasikan program studi tertentu, khususnya program studi PBA STAIN Datokarama Palu di tengah-tengah masyarakat.

\section{Langkah-langkah yang Perlu Dilakukan untuk Menarik Minat Calon Mahasiswa Memilih PBA}

Ada beberapa langkah yang perlu dilakukan untuk menarik minat mahasiswa memilih program studi PBA dalam melanjutkan studinya di STAIN Datokarama Palu.

\section{Sosialisasi yang Berkesinambungan}

Melihat kurangnya mahasiswa memilih PBA untuk melanjutkan studinya di STAIN Datokarama Palu, diperlukan kerja keras dari berbagai pihak yang terkait untuk memperkenalkan kepada calon- 
calon mahasiswa tentang keberadaan program studi PBA. Ramang, Ketua Jurusan Tarbiyah, mengatakan:

Sosialisasi yang terus-menerus perlu dilakukan oleh semua dosen, khususnya dosen-dosen bahasa Arab ke sekolah-sekolah. Ia menekankan perlunya pula kerjasama dengan para kepala sekolah, wakil kepala sekolah, serta guru-guru lainnya, terutama guru bahasa Arab dan guru Pendidikan Agama Islam untuk sosialisasi tersebut. (Wawancara, 14 Juni 2006).

M. Hasan, ketua program studi PBA, mengatakan:

Agar sosialisasi tersebut diperlukan dan dilakukan terlebih dahulu sebelum masuk catur wulan ke-3 (Semester 2) di SMA, MA maupun sekolah sederajat yang melibatkan semua unsur yang ada di sekolah melalui kerja sama dengan kepala sekolah, wakil kepala sekolah, wali kelas, serta guru-guru lainnya, terutama guru bahasa Arab dan guru Pendidikan Agama Islam untuk sosialisasi tersebut (Wawancara, 23 Juli 2006).

\section{Penyediaan Lapangan Kerja}

Upaya lain yang sangat urgen dilakukan untuk menarik minat mahasiswa memilih program studi PBA adalah menyediaan lapangan pekerjaan. Asmawi mengusulkan perlunya dibuka tempat-tempat kursus bahasa Arab yang dikelola oleh alumni program studi PBA sehingga alumni program studi PBA tidak hanya terfokus menjadi Pegawai Negeri Sipil (PNS). Jika hal ini terlaksana dengan baik maka tidak menutup kemungkinan minat para calon mahasiswa untuk memilih program studi PBA akan meningkat (Wawancara, 19 Juni 2006).

Selain itu, perlu pula dilakukan upaya-upaya pemberdayaan alumni program studi PBA melalui pelatihan-pelatihan khusus. Misalnya, pelatihan profesional bagi alumnus program studi ini untuk dipersiapkan menjadi tenaga profesional yang dapat dipekerjakan sebagai Tenaga Kerja Indonesia (TKI) ke beberapa negara di Timur Tengah. Oleh karena itu, STAIN Datokarama Palu perlu mempersiapkan tempat pelatihan bahasa Arab dan pelatihan kerja yang berhubungan dengan ketenagakerjaan. Selain itu, hubungan kerja sama dengan unsur-unsur terkait perlu dipersiapkan untuk pengiriman tenaga kerja tersebut. 


\section{Kerja sama dengan Pemerintah untuk Penerimaan CPNS bagi Lulusan Program Studi PBA}

Dalam hal perlunya kerja sama dengan pemerintah untuk memberdayakan alumni PBA STAIN Datokarama Palu, Abd. Rahim mengatakan bahwa:

STAIN Datokarama Palu perlu bekerja sama dengan Departemen Agama R.I. agar alumni program studi PBA diberi jatah khusus dalam formasi penerimaan CPNS untuk menarik minat mahasiswa memilih program studi PBA ketika melanjutkan studinya di STAIN Datokarama Palu. Selain Departemen Agama R.I, kerja sama juga perlu dilakukan dengan Pemerintah Daerah, khususnya Dinas Pendidikan dan Pengajaran agar alumni program studi PBA diberi formasi pada pengangkatan CPNS. Selain itu, mereka diberikan pula peluang untuk mengikuti seleksi Guru Tidak Tetap (GTT) serta Guru Bantu Sekolah (GBS) yang dibuka oleh Dinas Pendidikan dan Pengajaran. Hal ini penting agar asumsi masyarakat tentang kurang peluang alumni PBA direkrut menjadi PNS dapat berkurang (Wawancara, 17 Juni 2006).

Selain itu, bimbingan bahasa Arab terhadap siswa/calon mahasiswa di sekolah-sekolah sangat diperlukan agar mereka semakin mantap dan kuat minatnya untuk melanjutkan studinya pada program studi PBA. Dengan bimbingan ini, tidak menutup kemungkinan siswa yang awalnya tidak berminat memilih program studi PBA menjadi berminat.

M. Hasan mengatakan bahwa:

Bimbingan khusus bahasa Arab pada sekolah-sekolah untuk menarik minat calon mahasiswa memilih pogram studi PBA perlu dilakukan. Agar bimbingan ini berjalan maka diperlukan jadwal khusus di antara dosen bahasa Arab untuk memberikan bimbingan bahasa Arab di sekolah-sekolah setiap minggunya secara reguler (Wawancara, 23 Juli 2006).

Selain itu, bimbingan bahasa Arab juga diberikan kepada mahasiswa yang telah memilih program studi PBA sebagai tempatnya untuk menuntut ilmu di STAIN Datokarama Palu. Hal ini dimaksudkan agar mereka merasa memiliki program studi PBA sehingga enggan untuk pindah ke program studi lain. 


\section{Perbaikan Kurikulum}

Adanya mahasiswa program studi PBA yang pindah ke program studi yang lain disinyalir disebabkan adanya perbedaan kurikulum yang mencolok antara program studi PBA dengan program studi yang lain. Oleh karena itu, perbaikan kurikulum pada program studi PBA sangat diperlukan. Hal ini dimaksudkan agar ada keseragaman materi perkuliahan yang diajarkan. Ramang, ketua Jurusan Tarbiyah, mengatakan:

Kurikulum bahasa Arab harus diperbarui untuk mendapatkan keseragaman materi yang disampaikan di perkuliahan karena ada mahasiswa yang tadinya masuk ke program studi PBA, namun tibatiba pindah ke program studi yang lain (Wawancara, 14 Juni 2006).

Seandainya materi perkuliahan yang diajarkan pada program studi lainnya seragam, mahasiswa program studi PBA tidak akan pindah ke program studi yang lain. Mereka dapat belajar bahasa Arab melalui bimbingan-bimbingan tambahan yang diberikan oleh dosen. Dengan demikian, program studi PBA perlu membuat programprogram tambahan sehingga akan memberikan dampak pada peningkatan minat calon mahasiswa dalam memilih program studi PBA.

\section{PENUTUP}

Berdasarkan uraian sebelumnya, dapat disimpulkan bahwa kurangnya minat para calon mahasiswa untuk memilih program studi PBA sangat berkaitan dengan (1) kurangnya kesempatan untuk memperoleh pekerjaan, terutama menjadi pegawai negeri sipil; (2) hubungan calon mahasiswa antara satu sama lain yang saling mengajak untuk masuk atau melanjutkan studinya di STAIN Datokarama Palu pada satu program studi tertentu; (3) kurangnya sosialisasi khusus untuk program studi PBA juga berperan sehingga calon mahasiswa kurang mendapatkan informasi yang cukup tentang keberadaan program studi ini. Untuk meningkatkan minat para calon mahasiswa untuk memilih program studi PBA, diperlukan langkahlangkah konkret, antara lain, yaitu sosialisasi yang berkesinambungan dan penyediaan lapangan kerja, terutama pengangkatan sarjana bahasa Arab menjadi pegawai negeri sipil, membuka kursus-kursus bahasa Arab yang dikelola oleh alumni program studi PBA, dan 
pengiriman alumni program studi PBA sebagai Tenaga Kerja Indonesia (TKI) di beberapa negara Timur Tengah.

\section{DAFTAR PUSTAKA}

Ali, Muhammad. 1993. Strategi Penelitian Pendidikan. Cet. ke-10. Bandung: Angkasa.

Arsyad, Azhar. "Bahasa Arab dan peranannya dalam meningkatkan Kualitas Alumni" Makalah, disampaikan pada Studium General Fakultas Tarbiyah Universitas Muslim Indonesia pada tanggal 12 September 1994.

al-Ghazâlî, Abû H amid Muh ammad bin Muh ammad. 1390 H/1971. AlMustasfâ min 'Ilm al-Us ul. Juz I. Mesir: Mu'assasat al-Halabî.

al-Ghulâyânî. 1992. Jâmi' al-Durûs al-'Arabiyyah. Jilid I. Semarang: Asy Syifa'.

Demand, Helga. 1993. Pengambilan Keputusan yang Efektif. Jakarta: Gramedia Pustaka Utama.

Departemen Pendidikan dan Kebudayaan R.I. 1990. Kamus Besar Bahasa Indonesia. Cet. ke-3. Jakarta: Balai Pustaka.

Marimba, Ahmad D., t.th. Pengantar Filsafat Pendidikan Islam. Bandung: Al-Ma'arif.

Purwadarminta, W.J.S. 1985. Kamus Umum Bahasa Indonesia. Jakarta: Balai Pustaka.

Taher, Mursal M. 1981. Kamus Ilmu Jiwa dan Pendidikan. Cet. ke-3. Bandung: Al-Ma'arif. 